\title{
Jamaican Spices as Food Preservatives
}

\section{Roy B. R. Porter ${ }^{1}$, Lawrence A. D. Williams ${ }^{2}$, Grace-Ann O. Junor ${ }^{1}$ and Cheryl Green ${ }^{2}$}

${ }^{1}$ Chemistry Department, University of the West Indies, Mona Campus, Kingston 7, Jamaica, West Indies.

${ }^{2}$ Scientific Research Council, Hope Gardens, P.O. Box 350, Kingston 6, Jamaica, West Indies.

\begin{abstract}
The present review is a compilation of the spices commonly used in Jamaica for preserving foods especially meats. These include: Allium cepa L. (onion), Allium fistulosum L. (Escallion), Allium sativum L. (Garlic), Capsicum annum L. (Scoth bonnet), Capsicum frutescens L. (Bird pepper), Curcuma domestica Valeton (Turmeric), Cinnamomum zelanicum Nees (Cinnamon), Pimenta dioica (L.) Merr (Pimenta), Plectranthus amboinicus (Lour) Launert (French thyme), Rosmarinus officinalis L. (Rosemary), Thymus vulgaris L. (Thyme) and Zingiber officinale Roscoe (Ginger).
\end{abstract}

Keywords: Antioxidant, antimicrobial, oleoresin 


\section{INTRODUCTION}

Spices are used for the preservation of foods by preventing rancidity which could be linked to the processes of enzymic hydrolysis, autoxidation, bond cleavage and enzymic decarboxylation (Pokorny, 1999). Spices often possess dual modes of action. Some may be antioxidative and/or antimicrobial in nature, e.g. Cinnamonum zeylanicum (Cinnamon), Curcuma longa (Turmeric) and Pimenta dioica (Pimento) are antioxidants (Williams, 2006), while garlic (Allium sativum) and thyme (Thymus vulgaris) are antibacterial in nature (Marino et al., 1999; Sasaki et. al., 1999).

\section{Allium cepa L. (Onion)}

Onion is a spice widely used in meat preservation. The spice has antimicrobial (DE WIT et.al., 1979) and antioxidant activities (Ingunn and Rune, 2008). The plant contains the following sulphur compounds; (1) propyl disulphide, (2) propyl trisulphide, (3) methyl propyl disulphide and (4) methyl propyl trisulphide which are responsible for its antimicrobial activity (IN-HO et al., 2007). (4a) Kaempferol-3-Oglucopyranoside (Astragalin) a known antioxidant has been reported to be present in Allium cepa (Muminova et al., 2006).

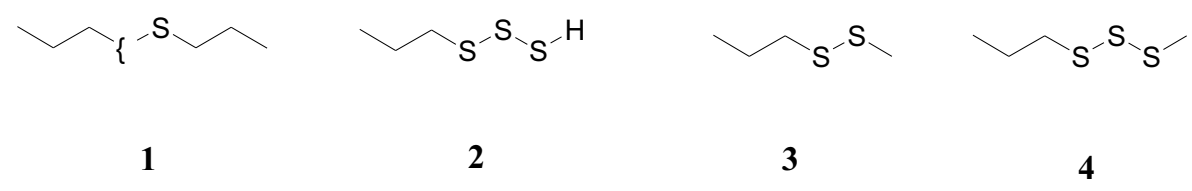<smiles></smiles> 


\section{Allium fistulosum L. (Escallion)}

The Allium fistulosum which is used for cooking is rich in sulphur compounds, e.g. (5) diethyl disulfide and (6) diallyl disulfide. These are known to possess an antimicrobial activity (Tada et al., 1988).

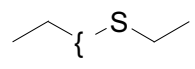

5

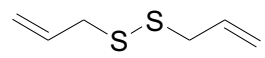

6

\section{Allium sativum L(Garlic)}

Garlic consists several compounds known for their anti-hypertensive and antimicrobial activties. These compounds include (7) allicin , (8) ajoene, 2-vinyl-4H-1, (9) 3-dithiine , (10) dially trisulphide and (11) methyl allyl trisulfide. This spice is used as an antimicrobial agent in preserving meat (Sasaki et. al., 1999).<smiles></smiles>

7<smiles>C=CCSSC/C=C/CSSCC=C</smiles>

8<smiles>C=CC1SC=CCS1</smiles>

9

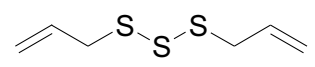

10<smiles>C=CCSSSC</smiles>

11

Capsicum annum L. (Scotch Bonnet) and Capsicum frutescens L. (Bird pepper)

Capsicum annum and Capsicum frutescens are used in the cooking of meats and soups. They possess antioxidant property which may be linked to the polyphenols that they contain, e.g. (12) quercetin, (13) luteolin and (14) $\beta$-carotene (Sun et al., 2007). In addition, the extracts of $C$. annum and C. frutescens contain (15) capsaicin and (16) capsanthin, which are known to possess antioxidants (Sun et al., 2007). 
<smiles>O=c1c(O)c(-c2ccc(O)c(O)c2)[pH]c2cc(O)cc(O)c12</smiles>

12<smiles>O=c1cc(-c2ccc(O)c(O)c2)oc2cc(O)cc(O)c12</smiles>

13<smiles>CC1=C(/C=C/C(C)=C/C=C/C(C)=C/C=C/C=C(C)/C=C/C=C(C)/C=C/C2=C(C)CCCC2(C)C)C(C)(C)CCC1</smiles>

14<smiles>COc1cc(CNC(=O)CCCC/C=C/C(C)C)ccc1O</smiles>

15<smiles>CC1=C(/C=C/C(C)=C/C=C/C(C)=C/C=C/C=C(C)/C=C/C=C(C)/C=C/C(=O)[C@@]2(C)C[C@@H](O)CC2(C)C)C(C)(C)C[C@H](O)C1</smiles> 


\section{Cinnamoum zeylanicum Nees (Cinnamon).}

Cinnamon is a spice used in cooking, the baking of cakes and cookies and for flavouring. The oleoresin of $C$. zeylanicum consists of alcohols, aldehydes, ketones, phenols, terpenes, sesquiterpnenes esters, lactones and ethers (Jayaprakasha et al., 2002). C. zeylanicum is a spice that has high antioxidant activity as it is dominated by the phenols (Williams, 2006).

\section{Curcuma longa Valeton (Turmeric)}

C. longa is a spice used in the preparation of curry (dried powder of $C$. longa). The oleoresin of $C$. longa consists of curcuminoids which are antioxidative in nature and are used as preservative in foods. There are three major curcuminoids present in C. longa namely; (17) diferuloyl methane (curcumin), (18) demethoxy curcumin and (19) bisdemethoxy curcumin (Jayaprakasha et al., 2006).<smiles>COc1cc(/C=C/C(=O)CC(=O)/C=C/c2ccc(O)c(OC)c2)ccc1O</smiles>

17<smiles>COc1cc(/C=C/C(=O)CC(=O)/C=C/c2ccc(O)cc2)ccc1O</smiles>

18<smiles>O=C(/C=C/c1ccc(O)cc1)CC(=O)/C=C/c1ccc(O)cc1</smiles>

19

\section{Pimenta dioica L. (Pimenta)}

P. dioica, commonly known as 'all spice', is used for preserving meats. The oleoresin of $P$. dioica contains a high percentage of (20) phenyl propanoids, eugenol, (21) iso-eugenol and (22) methyl eugenol (Brown et al., 1998). These compounds are antioxidant and antimicrobial in nature (Vasques E.A., 2000; Kurkin, 2003). 
<smiles>C=CCc1ccc(O)c(PC)c1</smiles>

20<smiles>C/C=C/c1ccc(O)c(OC)c1</smiles>

21<smiles>C=CCc1ccc(OC)c(OC)c1</smiles>

22

\section{Plectranthus amboinicus Lour (Launert) (French thyme)}

French thyme is a spice used in cooking. The oleoresin of $P$. amboinicus consists of the (23) monoterpenoids $\gamma$-terpinene, (24) carvacrol, (25) $\alpha$ terpinene, (26) limonene and the (27) sesquiterpenoid $\beta$-caryophyllene with low (approximately $23 \%$ ), antioxidant and antimicrobial activities (Williams, 2006).<smiles>CC1=CCC(C(C)C)=CC1</smiles>

93<smiles>Cc1ccc(C(C)C)cc1O</smiles>

24

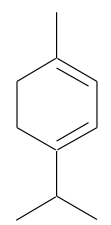

25<smiles>C=C(C)C1CC=C(C)CC1</smiles>

26

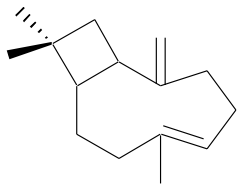

27

\section{Rosmarinus officinalis L. (Rosemary)}

R. officinalis is a spice, whose oleoresin contains several compounds such as, (28) rosmanol, (29) rosmaridiphenol, (30) rosmarinic acid, (31) carnosol, (32) carnosic acid and (33) ursolic acid that are ideal for meat and oil preservation (Offord etal., 1995; Hibbert etal., 2006).

\section{Thymus vulgaris L. (Thyme)}

Thyme is a spice with antibacterial activity used for preserving meat (Marino et al., 1999). The oleoresin consists of the (34) monoterpenoids cineol, (35) $p$-cymene, (36) $\alpha$-pinene, (37) thymol methyl ether, (38) carvacrol and (39) thymol. The named compounds are known for their antimicrobial activity (Marino et al., 1999). 


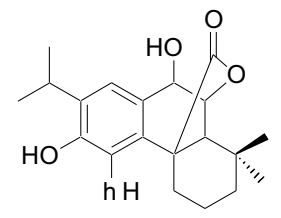

28

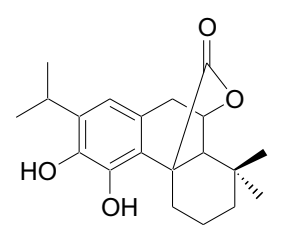

31

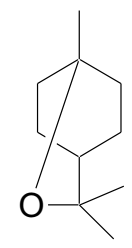

34<smiles>Cc1ccc(C(C)C)cc1O</smiles>

8

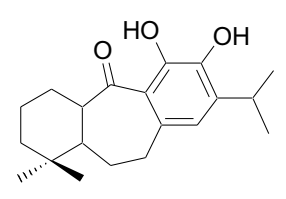

29

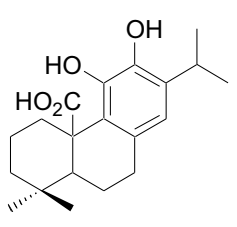

32

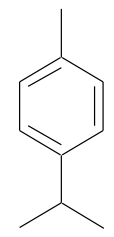

35<smiles>Cc1ccc(C(C)C)c(O)c1</smiles>

39<smiles>O=C(CCc1ccc(O)c(O)c1)OC(Cc1ccc(O)c(O)c1)C(=O)O</smiles>

30<smiles>C[C@H]1CCC2(C(=O)O)CC[C@]3(C)C(=CCC4[C@@]5(C)CC[C@@H](O)C(C)(C)C5CC[C@]43C)C2[C@@H]1C</smiles>

33

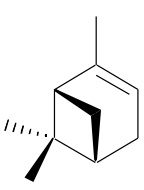<smiles>COc1cc(C)ccc1C(C)C</smiles> 


\section{Zingiber officinale Roscoe (Ginger)}

Two varieties, namely, blue and yellow ginger are used in cooking throughout Jamaica. The main composition of the essential oils of the blue and yellow varieties are: (40) zingiberenE, (41) $\alpha$-farnesene and (42) camphene. Shogaols and gingerols are the main composition of the oleoresin in both varieties (Lantz et al., 2007). These compounds are responsible for the biological activities of ginger, for instance, antioxidant activity and medicinal properties (relief of stomach ache and nausea) (Bailey-Shaw et al., 2008).

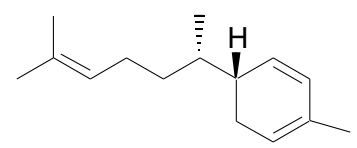

ज)

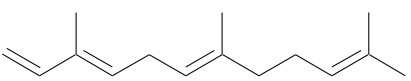

41

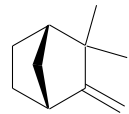

42

\section{REFERENCES}

BAILEY-SHAW Y.A., L.A.D. WILLIAMS, G-A.O. JUNOR, C.E. GREEN, S.L. HIBBERT, C.N.A. SALMON, A.M. SMITH (2008) Changes in the contents ofoleoresin and pungent bioactive principles of Jamaica ginger (Zingiber officinale Roscoe) during maturation. Journal of Agriculture Food Chemistry 56, 5564-5571.

BROWN H., D. MINOTT, C.W. INGRAM, L.A.D. WILLIAMS (1998) Acaricidal activities of Pimenta dioica extracts and compounds. Insect Science and its Application 18, 9-16.

DE WIT J.C., S.H.W. NOTERMANS, N. GORIN, (1979) The antimicrobial effects of onion and garlic extracts. Antonie van Leeuwenhoek 45, 156-158.

HIBBERT S.L., L.A.D. WILLIAMS, R.B.R. PORTER, Y.A. BAILEY-SHAW, C.E. GREEN, G-A.O. JUNOR, C. SALMON (2006) Local herb extracts as replacement for synthetic antioxidant in foods. Proceedings of the $20^{\text {th }}$ Annual Science and Technology Conference and Expo. Kingston, Jamaica. 
INGUNN M.V., S. RUNE (2008) Amount of characteristic compounds in 15 cultivars of onion (Allium cepa L.) in controlled field trials. Journal of the Science of Food and Agriculture 88, 404-411.

IN-HO C., S. SANG-CHUL, II-KWON P. (2007) Nematicidal activity of onion (Allium cepa) oil and its components against the pine wood nematode (Bursaphelenchus xylophilus). Nematology 9, 231-235.

JAYAPRAKASHA G.K., L.J. RAO, K.K. SAKARIAH (2002) Chemical composition of volatile oil from Cinnamomum zeylanicum Buds. Verlag der Zeitschrift fur Naturforschung 57c, 990-993.

JAYAPRAKASHA G.K., R. JAGANMOHAN, K.K. SAKARIAH (2006) Antioxidant activities of curcumin, demethoxycurmin and bisdemethoxycurcumin. Food Chemistry 98, 720-724.

KURKIN V.A. (2003) Phenylpropanoids from medicinal plants: Distribution, classification, structural analysis and biological activity. Chemistry of natural Compounds. 39, 123-153.

LANTZ R.C., G.J. CHEN, M. SARIHAN, A.M. SOLYOM, S.D JOLAD, B.N. TIMMERMANN (2007) The effect of extracts from ginger rhizome on inflammatory mediator. Phytomedicine 14, 123-128.

MARINO M., C. BERSANI, G. COMI (1999) Antimicrobial activity of the essential oils of Thymus vulgaris L. measured using a bioimpedometric method. Journal of Food Protection 62, 1017-23.

MUMINOVA B.A., E.K. BATIROV, M.P. YULDASHER, Z.G. INAMOVA (2006) Kaempferol glycosides from Allium cepa and Raphanus sativus. Chemistry of Natural Compounds. 42,110-111.

OFFORD E.A., K. MACE, C. RUFFIEUX, A. MALNOE, A.M. PFEIFER (1995) Rosemary component inhibit benzo[a]pyrene-induced genotoxicity in human bronchial cells. Carcinogenesis 16, 2057-2062.

POKORNY L. (1999) Antioxidant in Food Preservation. In: Handbook of Food Preservation (M. Rahman), Marcel Dekker, INC, NY, pp 309-337. 
SASAKI J., T. KITA, K. ISHITA, H. UCHISAWA, H. MATSUE (1999) Antibacterial activity of garlic powder against Escherichia coli 0-157. Journal Nutritional Science and Vitaminology 45, 785-90.

SUN T., Z. XU, C-T. WU, W. JANES, H.K.N.O. PRINYAWIWATKUL (2007) Antioxidant activities of different colored sweet bell peppers (Capsicum annum L.). Journal of Food Science 72, S98-S102.

TADA M., Y. HIROE, S. KIYOHARA, S. SUZUKI (1988) Nematicidal and antimicrobial constituents from Allium grayi Regel and Allium fistulosum L. var. caespitosum. Agricultural and Biological Chemistry $\mathbf{5 2}, 2383-2385$.

VASQUES E.A., Pesticidal and Other Biological Activities of Selected Philippine Plant Species and Bioactive Compounds from: Derris philippinenesis Merr. (Fabaceae), Coleus amboincus Merr. (Lamiaceae) and Mikania cordata (Burm.) B.L. Robinson. Typoskript Edition. Hieronymus, Muenchen, Gemany, 217 pp.

WILLIAMS L.A.D., S.L. HIBBERT, R.B.R. PORTER, Y. A. BAILEY-SHAW, C.E. GREEN (2006) Jamaican plants with in vitro anti-oxidant activity. In: Biological active natural products for the $21^{\text {st }}$ Century (L. Williams), Research Signpost, Trivandrum India, pp 1-12. 